Research Article

\title{
An Empirical Analysis of Firm-Specific Factors and Equity Premium: Evidence from Manufacturing Sector of Pakistan
}

\author{
Mengyun Wu $\mathbb{D},{ }^{1}$ Muhammad Imran $\mathbb{D}^{1},{ }^{1}$ Linrong Zhang $\mathbb{D},{ }^{1}$ Qi He, ${ }^{1}$ and Allah Yar ${ }^{2}$ \\ ${ }^{1}$ School of Finance and Economics, Jiangsu University, Zhenjiang, Jiangsu 212013, China \\ ${ }^{2}$ Khyber Pakhtunkhwa Higher Education Department, Peshawar 25000, Pakistan \\ Correspondence should be addressed to Muhammad Imran; imran@ujs.edu.cn
}

Received 19 November 2019; Accepted 22 May 2020; Published 27 June 2020

Academic Editor: António M. Lopes

Copyright (C) 2020 Mengyun Wu et al. This is an open access article distributed under the Creative Commons Attribution License, which permits unrestricted use, distribution, and reproduction in any medium, provided the original work is properly cited.

\begin{abstract}
Equity premium is a vital number in finance to be considered for making fund allocation and investment decisions. This study explores the relationship between (controllable) determinants of firm-level equity premium in the context of Pakistan stock market. We use a sample of 306 firms' annual data, from 01/2001 to 6/2017, using a two-stage least-squares method to estimate our model. During the selected sample period, the average market premium of the Pakistan stock exchange (KSE100 Index) was twenty percent. The average equity premium of individual firms was only eight percent. Company fundamentals are considered determinants of firm-level equity premiums. Panel data econometrics techniques were used to estimate the modified version of the multifactor model for the Pakistan Stock Exchange. It is found that the market premium, return on equity, dividend payout ratio, accounts receivable, and firm size significantly and positively affect the firm-level equity premium. However, increase in the debtto-equity ratio and quick ratio negatively affects that premium. The company fundamental variables are controllable for the firms and can be improved by company management to encourage investors and maximize shareholder wealth.
\end{abstract}

\section{Introduction}

One of the most pressing, contemporary topics in advanced corporate finance and financial economics is the equity premium and the magnitude of that equity premium in total returns. The equity premium is the additional return that investors require from investing in riskier stocks rather than in risk-free securities. The risk premium drives the total expected stock returns and is a key determinant of the cost of equity. Fama and French [1] define the equity risk premium as the difference between expected market portfolio return and the risk-free rate of return. Similarly, according to Mehra and Prescott [2], the difference between the market portfolio of stock and the risk-free interest rate is excess return, and this is called the equity premium.

Damodaran $[3,4]$ has stated that the stock risk premium is a central figure on which investors insist for a high return from investing in the stock market because the stock market risk is higher than the money market risk. Based on theoretical assumptions, the equity premium is the reward for taking that higher risk. It is a major factor for investors in estimating the total expected return of venture capital investment demand. It is also an important contribution to the valuation of corporate finance and market securities. Recently, Damodaran [4] stressed the importance of previous equity risk premiums and conducted empirical studies using data from 1926 to 2015. It was found that the average equity premium during this period was only $3.68 \%$, with SD of $1.91 \%$.

Equity premiums are estimated in many asset pricing models, such as APTs, three-factor models, and multifactor models. Many studies have validated the Capital Asset Pricing Model (CAPM), which is the origin of the equity premium in various capital markets [5-7]. The preliminary empirical test of CAPM predicts a positive statistically significant intercept term and concludes that the CAPM corresponds to the expected return of the market. The 
CAPM also has a linear relationship with the actual calculated return of the market portfolio.

While studying the drivers of the equity premium, one cannot ignore the importance of noneconomic factors that affect stock returns in general and equity premiums. In particular, Chen and Siems [8], Chesney et al. [9], Aisen and Veiga [10], Essaddam and Karagianis [11], Mnasri et al. [12], Okafor [13], Apergis and Apergis [14], Hobbs et al. [15], and Mnasri and Nechi [16], inter alia, have studied the impact of noneconomic factors such as political corruption, law and order, government regime changes, and political stability on stock market returns and equity premiums. Macroeconomic and noneconomic factors are beyond the control of fund managers and firm managers. Investors need to diversify their investment to minimize their risk, and the firm needs to make necessary changes that respond to changes in macro and noneconomic factors.

In Pakistan, a number of related studies [17-20] address stock market returns, their implications, determinants, and the interrelation with global markets. However, to the best of the authors' knowledge, there are very limited number of studies on market premiums and none on firm-level equity premiums. Research into the firm-level equity premium, its size in total expected returns for individual assets, its estimation, importance, and the equity premium determinants remain scant in the literature.

\section{Literature Review}

The most popular fund allocations and investment decisions were based on mean-variance analysis. Markowitz [21] and Tobin [22] introduced the mean-variance rule. This seems to have been the first and most used investment allocation tool to address uncertainty in economics and finance. It has been broadly used by academics and investment practitioners. The same mean-variance analysis framework is the basis of Sharpe's [23] and Linter's [24] CAPM, which is the cornerstone of today's modern economics and finance and other theoretical models. Blanchard [25], Lamont [26], Fama and French [1], and Gordon and Halpern [27] examined company fundamentals using a dividend growth model and concluded that changing price earnings ratios and dividends can also change the magnitude of the equity premium, which translates into a decrease in the total expected rate of return. They also concluded that dividends and price earnings ratios are the most basic company fundamental factors that affect the equity risk premium. Mehra and Prescott [2], Haque and Sarwar [28], and Imran et al. [29] argue that the equity risk premium is important for making various decisions such as portfolio allocation decisions, in deciding about the cost of capital, for determining the compensation for investing social security funds in the equity market, and many more such applications. Glassman and Hassett [30] state that equity premiums arise from errors. They further argue that the change in the risk-free rate produces the premium. When interest rates increase, the equity premium tends towards zero. These studies are mostly related to market premiums rather than firm-level equity premiums. Our study is different in that we examine the impact of company fundamentals on firm-level equity premiums, which is poorly represented in the available literature.

Fernandez [31] conducted a survey and received responses from 85 countries, including Pakistan; the survey asked about the required market risk premium (MRP). The average MRP reported for Pakistan was 6.3, with a standard deviation (SD) of 2.3; the study concluded that Pakistan is a developing capital market. The discount rate was not statistically significantly correlated with the developed world, especially Western Europe and the United States. Therefore, most of the macroeconomic and monetary economic indicators do not adequately explain the situation of the Pakistan stock market return, and in fact this is true for all developing economies. "The country has a very large undocumented sector and very limited tax base, and its policies-for the most part-are not set independent of international political pressures" [31]. We predict from these studies that the equity premium of the Pakistan stock market is not properly calculated in any empirical study nor have its determinants been examined.

In the equity premium survey, Fernandez [31] reported considerable variation in equity premiums across economic analysts within the same stock market. In the United States, for example, the average equity risk premium across analysts was $5.8 \%$. However, the numbers produced by different academic and economic experts ranged from $3.2 \%$ to $10.5 \%$. Therefore, an extensive investigation of the market equity premium, as well as of firm-level equity premium, is of paramount importance. Company fundamentals, as determinants of the firm-level equity premium, will open avenues for further research into this topic for future decision making that will be relevant to internal factors of firm performance.

Since we know that the company's risk should be determined by a combination of the fundamentals and the market characteristics of the company's stock, this study differentiates itself from earlier studies by taking into account the firm-level equity premium with its internal risks of its fundamentals. This is important to study because company fundamentals are controllable and the firm's management can take any necessary action to improve them and encourage investors.

\section{Model}

Equity premium can be modelled using different asset pricing models such as CAPM, APT, the three-factor model, and multifactor models. Markowitz [21] was the first to provide the basis of the risk and return theory. Markowitz's theory was further developed and constructed into the CAPM by Tobin [22], Sharpe [23], Linter [24], and Mossin [32]. The CAPM was criticised for its single-factor measure, which gave birth to Arbitrage Pricing Theory [33], followed by the three-factor model $[34,35]$ and the multifactor model [1]. Relevant to the different degrees of risk, macro-based and micro-based risk factor models were also developed accordingly. However, there remains room to add new phenomena of company fundamental factors in order to evaluate the association between the equity premium and its 
possible determinants. In this study, we will use a modified version of Fama and French's [1] multifactor model to examine the effect of company fundamental variables (i.e., market premium, liquidity, solvency, efficiency, and size) on firm-level equity premiums in Pakistan. The model is explained in the following formula:

$$
\begin{aligned}
\mathrm{EP}_{i t}= & \alpha i+\beta_{i 0}\left(\mathrm{MP}_{T}\right)+\beta_{i 1}\left(\mathrm{ROE}_{T}\right)+\beta_{i 2}\left(\mathrm{QR}_{T}\right) \\
& +\beta_{i 3}\left(\mathrm{DPR}_{T}\right)+\beta_{i 4}\left(\mathrm{DER}_{T}\right)+\beta_{i 5}\left(\mathrm{ART}_{T}\right) \\
& +\beta_{i 6}(\mathrm{Size})+\varepsilon_{i t},
\end{aligned}
$$

where $\mathrm{EP}_{i t}$ is the firm-level equity premium, $\mathrm{MP}_{T}$ is the market premium, $\mathrm{ROE}$ is return on equity, $\mathrm{QR}$ is the quick ratio proxied for liquidity of the firm, DPR is the dividend payout ratio, DER is the debt-to-equity ratio, ART is the accounts receivable turnover in days, Size represents the firm size, which is calculated as the log of total assets, and $\varepsilon_{i t}$ is the error term.

Previous studies $[1,4,35,36]$ considered variables such as growth, size, momentum, and macroeconomic factors. However, the company-specific microvariables are also used as technical indicators for investment decision making. Changes in investor preferences are also caused by the company's fundamental performance. This enables the firm to take necessary measures and to improve them because these factors are avoidable and they can be controlled by the firms themselves. MP represents the trend of the overall market. When the market premium increases, this means that investors are investing in different market portfolios, which result in increases in EP of firms. Therefore, the expected sign of the coefficient of MP is positive, i.e., $\beta_{0}>0$. ROE also provides the magnitude of the return on equity, which encourages (or discourages) investors to invest in those particular firms. Thus, the sign of the coefficient $\beta_{1}$ is expected to be positive, i.e., $\beta_{0}>0$. Similarly, increases in the value of DPR, ART, and Size encourage investors in that particular firm and the expected sign of the coefficient of these variables will be positive, i.e., $\beta_{3}>0, \beta_{5}>0$, and $\beta_{6}>0$. In turn, the effect of $\mathrm{QR}$ and DER on the firm's equity premium is expected to be negative. Thus, the expected sign of the coefficient is negative, i.e., $\beta_{2}<0$ and $\beta_{4}<0$.

\subsection{Econometric Methodology}

3.1.1. Data Collection and Research Methodology. This study selects 306 nonfinancial firms listed on the Pakistan Stock Exchange. This selection is made by keeping in view the liquidity of listed firms. Table 1 shows the descriptive statistics.

The data have been collected from reliable sources of the PSX official website (http://www.kse.gov.pk), business recorders, and economic surveys of Pakistan. The company fundamental variables, i.e., accounting data, are collected from the balance sheet analysis compiled by the State Bank of Pakistan. These are the most reliable sources of such financial information.

The following section discusses the methodology used for the estimation of the relation of the equity premium and its determinants. The study uses the assumption of continuous returns for the KSE100 Index and the asset prices of each firm. The continuously compounded returns formula is expressed as follows:

$$
\begin{aligned}
\text { future value } & =\text { present value } \times e^{i n}, \\
R_{t} & =\ln \left(\frac{P_{t}}{P_{t-1}}\right)
\end{aligned}
$$

where $R_{t}$ is the compounded return, $P_{t}$ is the price of asset at period " $t$," and $P_{t-1}$ is the price of assets at the period " $t-1$."

After calculating the returns of the KSE100 Index and firm assets, we can calculate the equity premium by taking the difference of market return and risk-free interest rate following the Fama and French [1] method:

$$
\mathrm{ER}_{i}=R_{m}-R_{f}
$$

where $\mathrm{ER}_{i}$ is the equity premium, $R_{m}$ is the return of the market, and $R_{f}$ is the risk-free rate of return.

3.2. Panel Data Econometrics. Panel or longitudinal data are a dataset which comprises repeated measures of a given sample or same variable over time, such as individuals, firms, persons, cities, and countries that are observed at numerous points in time such as days, months, quarterly, or years before and after treatment [37]. In the literature, it is known by various terms, such as pooled data, micropanel data, a combination of time series and cross section data, longitudinal data, and cohort analysis. Panel datasets are divided into micro- and macropanel datasets and balanced and unbalanced panel datasets. Micropanel datasets are those for which the time dimension, $T$, is of less importance than the dimension of individual $N$, while for macropanel data, the dimension of time $T$ and the individual $N$ are similarly important. A panel dataset is called balanced if it has the same time intervals, $t=1, \ldots, T$, for each cross section observation; for an unbalanced set, the time $T$ dimension is specific to each individual [37].

The general model for panel data can be written as

$$
Y_{i t}=\beta_{0}+\beta_{1} X_{i t}+v_{i t}+u_{i t}, \quad t=1,2, \ldots, T, i=1,2, \ldots, N,
$$

where $Y_{i t}$, is the dependent variable (in our case, we consider it as the firm-level equity premium), as usual $\beta_{0}$ is the intercept and independent from $i$ and $t, \beta_{1}$ is the $K \times 1$ vector of the unknown parameter to be estimated, $X_{i t}$ is the $1 \times k$ vector of explanatory variable observations, and $u_{i t}$ is the disturbance or error term.

The basic type model that can be estimated using the panel technique can be written as the following function:

$$
Y_{i t}=f\left(X_{i t}^{\prime} \beta\right)+\delta_{i}+\gamma_{t}+\epsilon .
$$

The most important case concerns the linear conditional mean specification so that we have the following functions:

$$
Y_{i t}=\alpha+X_{i t}^{\prime} \beta+\delta_{i}+\gamma_{t}+\varepsilon_{i t},
$$


Table 1: Descriptive statistics.

\begin{tabular}{|c|c|c|c|c|c|c|}
\hline Variables & Mean & Stand deviation & Minimum & Maximum & Skewnes & Kurtosis \\
\hline Equity premium & 0.0451 & 0.6056 & -3.86 & 5.39 & 0.173 & 3.693 \\
\hline Market premium & 0.1957 & 0.3959 & -1.01 & 0.71 & -1.863 & 3.473 \\
\hline Return on equity & 0.0069 & 5.1731 & -324.64 & 28.93 & -58.059 & 3.627 \\
\hline Quick ratio & 0.5141 & 2.9516 & 0.00 & 184.00 & 56.335 & 3.489 \\
\hline Dividend payout ratio & 2.9582 & 14.9081 & 0.00 & 749.71 & 31.940 & 1.489 \\
\hline Debt-to-equity ratio & 1.4811 & 41.8672 & -23.38 & 342.00 & -38.602 & 1.732 \\
\hline $\mathrm{A} / \mathrm{C}$ turnover ratio & 1.1876 & 1.1357 & 0.00 & 21.06 & 7.037 & 3.557 \\
\hline Size & 7.3540 & 1.7636 & -0.11 & 12.76 & -0.092 & 1.123 \\
\hline
\end{tabular}

where $Y_{i t}$ is the dependent variable, $X_{i t}$ is a $k$-vector of regressors, and $\epsilon_{i t}$ are the random error terms for $i=1,2,3, \ldots, M$ cross-sectional units observed for dated periods, i.e., $t=1,2,3, \ldots, T$. The $\alpha$ parameter indicates the overall constant in the above stated model, while the $\delta_{i}$ and $\gamma_{t}$ represent the cross sections for each period-specific effects (random or fixed). Random effect and fixed effect are the two most used methods for the analysis of cross-sectional datasets. However, generally there are three basic estimation models of panel data.

A decision to choose between the random effect model and the fixed effect model will be checked by using the Hausman test.

In order to estimate the model used in this study, we applied the two-stage least-squares (2SLS) method. The estimation of the model is not appropriately undertaken by using the simple ordinary least-squares method because the problem of possible endogeneity of the variables can cause the least-squares estimators to be biased and contradictory. Endogeneity is expected to occur mainly due to reverse causality between the independent variables (such as inflation and money supply); these same-nature variables are therefore likely to be correlated with the error term. To find reliable parameter estimates in panel data, we apply the two-stage least-squares estimation technique. This is based on the standard of variables used as instruments. In the presence of instrumental variables, two standard approaches to endogeneity in panel data are the panel two-stage least-squares (TSLS) estimator (e.g., among others, $[38,39])$ and the panel limited information maximum likelihood (LIML) estimator. Hence, in order to avoid the endogeneity problem, we use the TSLS (instrumental variables) to estimate our panel dataset.

3.3. The Hausman Test. The Hausman test is a standard method used in observation panel data analysis to distinguish between fixed effects and random effects models. This was used by Durbin and Stuart [40] and received good data analysis results. Therefore, an assessment test based on two sets of parameter estimates is called the Durbin-Wu-Hausman test, or DWH. For ease of description, we will refer to it as the Hausman [41] test.

The general procedure can be described as follows. We presume that we have two types of estimators for a certain factor " $\theta$ " of element $K \times 1$. One of them, $\widehat{\theta}_{r}$, is robust, i.e., reliable under both the null and alternative hypothesis. One of $\widehat{\theta}_{e}$ is capable and reliable under the null hypothesis $H_{0}$, but inconsistent under the alternative $H_{1}$. The variations between both the estimators are then used as the basis for testing the analysis. The Hausman test indicates that under appropriate assumptions, under $H_{0}$, the statistic $h$ based on $\left(\widehat{\theta}_{R}-\widehat{\theta}_{E}\right)$ has a limiting chi-squared distribution: $h=\left(\widehat{\theta}_{r}-\right.$ $\left.\hat{\theta}_{e}\right)\left[\operatorname{Var}\left(\hat{\theta}_{r}-\widehat{\theta}_{e}\right)\right]^{-1}\left(\hat{\theta}_{r}-\widehat{\theta}_{e}\right) \sim x_{K}^{2}$.

If this value lies in the upper tail of the chi-squared distribution, we reject our null hypothesis $H_{0}$ : if the variance matrix is consistently analyzed and estimated, the test will have more power against any other alternative under which $\widehat{\theta}_{r}$ is robust and $\widehat{\theta}_{e}$ is not robust.

The Hausman procedure also shows that, again under certain appropriate assumptions, $\operatorname{Var}\left(\widehat{\theta}_{r}-\widehat{\theta}_{e}\right)=\operatorname{Var}\left(\widehat{\theta}_{r}\right)-$ $\operatorname{Var}\left(\widehat{\theta}_{e}\right)$

It is well known that the assumptions used are sufficient but not necessary. Further, while it may be convenient to estimate

$$
\operatorname{Var}\left(\widehat{\theta}_{r}-\widehat{\theta}_{e}\right)=\operatorname{Var}\left(\widehat{\theta}_{r}\right)-2 \operatorname{Cov}\left(\widehat{\theta}_{r}, \widehat{\theta}_{e}\right)+\operatorname{Var}\left(\widehat{\theta}_{e}\right),
$$

this may be more robust and the trade-off between its robustness and power should be considered appropriately. The Hausman specification test for error components provides guidance on whether $E=\left(X_{i t} V_{i}\right) \neq 0$. The key idea is that if

$$
E=\left(X_{i t} V_{i}\right) \neq 0,
$$

then the inconsistent random effect estimator and the consistent fixed effect estimator converge to different estimates. If $E=\left(X_{i t} V_{i}\right)=0$, then the unobserved heterogeneity is uncorrelated with $X$ and does not create a base. Random effect and fixed effect are both consistent. However, the Hausman test can draw us away from using random effects in the existence of an outsized bias, but there remains room for substantial efficiency gains in switching to random effect.

\section{Results and Discussion}

This section explains the effect of company fundamentals on the firm-level equity risk premium. Company fundamental variables include market premium, ROE, QR, DER, DPR, ATR, and size of the company. Each of these variables has 4284 observations. 
4.1. Summary Statistics. Table 1 presents the descriptive statistics for the company fundamental variables used in this study. The results of these summary statistics include mean, minimum, maximum, standard deviation, skewness, and kurtosis.

These descriptive statistics show that the mean value of equity premium is 0.045 , with a range of -3.86 to $5.39 \%$ with a standard deviation of 0.60 . The mean of the market premium is 0.19 , with a range of -1.01 to $0.71 \%$ with a standard deviation of 0.39 . Return on equity (ROE) has the lowest mean of 0.007 , ranging from as low as -324.64 to 28.93 , with a high standard deviation value of 5.17 . The rest of the variables can also be interpreted in the same way. Size of the firm is an important component and has the highest mean of 7.35 , with a range of -0.11 to 12.76 ; this is followed by dividend payout ratio, which is also an important number in calculating the total return from an investment by investors and is followed by the mean of debt-to-equity ratio, i.e., 1.48. The standard deviation of debt-to-equity ratio is the highest, at 41.86 , followed by the standard deviation of dividend payout ratio, return on equity, and quick ratio.

Table 2 presents the results of the correlation matrix of the company fundamental variables. Values of correlation coefficients indicate that the market premium has a positive but insignificant correlation with ROE, debt-to-equity ratio, and accounts receivable turnover in days. However, it has a positive and significant relationship with QR. The market premium has significant negative correlation with size and negative but insignificant correlation with DPR. ROE is positively but insignificantly related with QR and dividend payout ratio; however, its positive and significant correlation is recorded with ATR. ROE shows a negative relationship with DER and Size but no negative significant correlation of ROE is recorded with other factors. The QR shows an insignificant positive correlation with DER, a negative insignificant relation with $\mathrm{DPR}$, and a negative but significant correlation with Size. DPR shows a positive and significant correlation with ATR and Size and a negative and insignificant correlation with DER. The factor DER has a positive relation with ATR and a negative relation with Size, but both values are statistically insignificant. In addition, ATR shows a negative and significant correlation with Size.

Table 3 presents the Kolmogorov-Smirnov test; the results demonstrate that $p$ value of the Kolmogorov-Smirnov test is greater than 0.05 which suggests that the data pattern of equity premium in our sample is normal. The same normality trend is also obtained by constructing a histogram (Figure 1).

To examine the structure break in the equity premium data, we have divided the data into two periods: before and after the 2008 global financial crisis. Period 1 consists of data from January 2001 to July 2008; period 2 consists of data from August 2008 to June 2017. Period 2 contains the crisis period, followed by the normal bullish market trend. A paired $t$-test is applied to check the differences of equity premium before and after the 2008 financial crisis. Table 4 presents the paired $t$-test results.

The results show that two pairs of equity premium are weakly and positively correlated $(r=0.243, p=0.00)$, since the $p$ value of $t$-statistics is insignificant (0.836), which implies that null hypothesis is accepted, i.e., there is no significant difference in returns before and after the global financial crisis.

4.2. Estimation and Interpretation of Results. We can estimate our model by the fixed effect or random effect technique in panel data econometrics, the most extensively used techniques. In order to select between them, we used the Hausman test, the most widely used technique for that selection. We estimate the following model by using the panel data for our sample variables for the period of January 2001 to December 2015:

$$
Y_{i t}=f\left(X_{i t}, \beta\right)+\theta_{i}+\gamma_{t}+v_{i t} .
$$

The model can be expressed in more compact form as follows:

$$
Y_{i t}=X_{i t} \beta+\theta_{i}+\gamma_{t}+v_{i t}
$$

The independent variables $X_{i t}$ are the company fundamentals. The others are as described earlier.

Table 5 presents the Hausman test results. The statistically insignificant value of the Hausman test indicates that the random effect is better than the fixed effect model.

We use the TSLS (instrumental variables) to estimate our panel dataset, a widely used technique for avoiding the problem of endogeneity $[38,39,42]$. The estimated results from the model are reported in Table 6 . The results show that the market premium has a positive and statistically significant impact on the firm-level equity risk premium. The value of the coefficient implies that a $1 \%$ increase in the market premium will increase the firmlevel equity premium by $0.55 \%$. The coefficient of the ROE is statistically significant and positive, which indicates that when the ROE increases by $1 \%$, the firm-level equity premium will increase by $0.003 \%$. The findings are consistent with previous studies. The coefficient of the QR is positive, which implies that quick ratio has a positive impact on equity premium. However, the coefficient of QR is statistically insignificant. The coefficient of the DPR is positive and statistically significant. This indicates that a $1 \%$ increase in DPR will increase the firm-level equity premium by $0.001 \%$. The statistically significant coefficient of the ATR indicates that a $1 \%$ increase in ATR will increase the firm-level equity premium by more than $0.02 \%$. These results are consistent with previous studies $[1,4,43]$. Size also has a statistically significant and 
TABLE 2: Correlation matrix of company fundamentals.

\begin{tabular}{|c|c|c|c|c|c|c|c|}
\hline Variables & MP & ROE & QR & DPR & DER & $\mathrm{A} / \mathrm{R} \mathrm{TR}$ & Size \\
\hline MP & 1 & & & & & & \\
\hline ROE & $\begin{array}{l}0.003 \\
0.868 \\
\end{array}$ & 1 & & & & & \\
\hline QR & $\begin{array}{c}0.08^{* *} \\
0.000 \\
\end{array}$ & $\begin{array}{l}0.001 \\
0.958 \\
\end{array}$ & 1 & & & & \\
\hline DPR & $\begin{array}{c}-0.013 \\
0.404\end{array}$ & $\begin{array}{l}0.018 \\
0.237\end{array}$ & $\begin{array}{c}-0.001 \\
0.973\end{array}$ & 1 & & & \\
\hline DER & $\begin{array}{l}0.010 \\
0.501\end{array}$ & $\begin{array}{c}-0.022 \\
0.142\end{array}$ & $\begin{array}{l}0.001 \\
0.935\end{array}$ & $\begin{array}{c}-0.001 \\
0.950\end{array}$ & 1 & & \\
\hline $\mathrm{A} / \mathrm{R} \mathrm{TR}$ & $\begin{array}{l}0.014 \\
0.370\end{array}$ & $\begin{array}{c}0.032^{*} \\
0.037\end{array}$ & $\begin{array}{c}-0.018 \\
0.240\end{array}$ & $\begin{array}{c}0.106^{* *} \\
0.000\end{array}$ & $\begin{array}{l}0.013 \\
0.411\end{array}$ & 1 & \\
\hline Size & $\begin{array}{c}-0.09^{* *} \\
0.000\end{array}$ & $\begin{array}{c}-0.024 \\
0.117\end{array}$ & $\begin{array}{c}-0.040^{* *} \\
0.009\end{array}$ & $\begin{array}{c}0.136^{* *} \\
0.000\end{array}$ & $\begin{array}{c}-0.023 \\
0.131\end{array}$ & $\begin{array}{c}-0.039^{*} \\
0.011\end{array}$ & 1 \\
\hline
\end{tabular}

TABLE 3: Normality test of dependent variable (equity premium).

\begin{tabular}{lccc}
\hline & Statistic & Kolmogorov-Smirnov $p$ value & Decision \\
\hline$H_{0}$ equity premium is normal & 0.659 & 0.076 & Retain null hypothesis \\
\hline
\end{tabular}

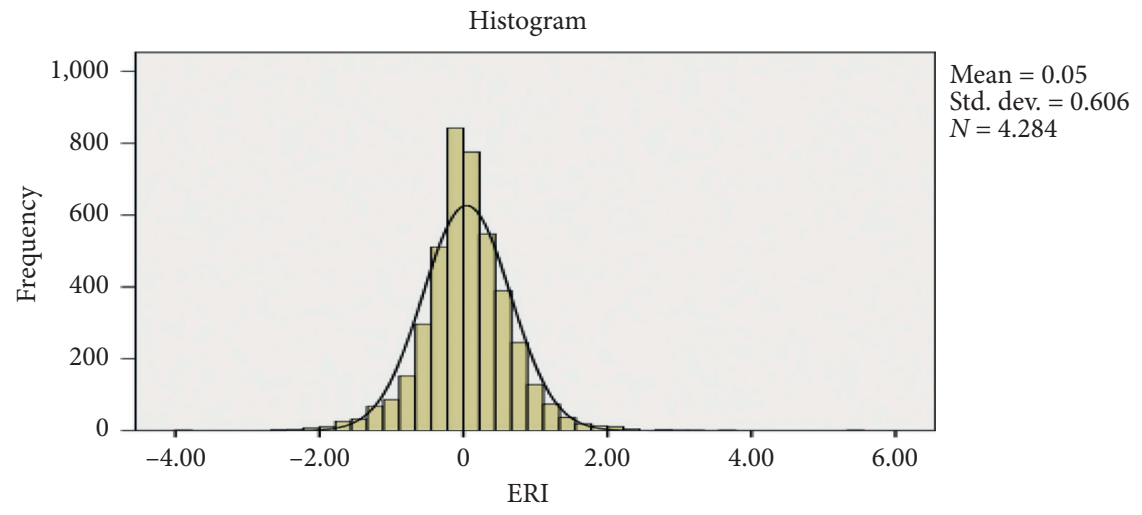

FIGURE 1: Normality plot of firm-level equity premium.

TABLe 4: Paired sample $t$-test.

\begin{tabular}{|c|c|c|c|c|c|c|c|c|}
\hline \multirow{4}{*}{$\begin{array}{l}\text { Variable } \\
\text { Equity premium } \\
\text { Pair-1 } \\
\text { Pair-2 }\end{array}$} & \multicolumn{5}{|c|}{ Paired sample statistics } & \multicolumn{3}{|c|}{ Paired correlations } \\
\hline & \multicolumn{2}{|c|}{ Mean } & SD & \multicolumn{2}{|c|}{ SE mean } & \multicolumn{2}{|c|}{ Statistic } & Sig \\
\hline & \multicolumn{2}{|c|}{0.0468} & 0.60087 & \multicolumn{2}{|c|}{0.01298} & \multirow{2}{*}{\multicolumn{2}{|c|}{0.249}} & 0 \\
\hline & & & 0.61049 & & & & & 0.000 \\
\hline \multicolumn{9}{|l|}{ Paired differences } \\
\hline & \multirow[t]{2}{*}{ Mean } & \multirow[t]{2}{*}{ SD } & SE & \multicolumn{2}{|c|}{$95 \% \mathrm{CI}$} & $T$ & Df & Sig \\
\hline & & & Mean & Lower & Upper & & & \\
\hline Pair 1-2 & 0.003 & 0.742 & 0.0160 & -0.028 & 0.035 & 0.208 & 2141 & 0.836 \\
\hline
\end{tabular}

TABLE 5: Correlated random effects-Hausman test.

\begin{tabular}{lccc}
\hline \multicolumn{4}{c}{ Test cross section random effects } \\
\hline Test summary & Chi-sq. statistic & Chi-sq. Df & Prob. \\
Cross section random & 4.89 & 7 & 0.67 \\
\hline
\end{tabular}


TABLE 6: Estimated results of equity premium.

\begin{tabular}{|c|c|}
\hline Variable & Coefficient \\
\hline Constant & -0.165 \\
\hline Market premium & $\begin{array}{c}0.551 \\
(24.656)^{*}\end{array}$ \\
\hline Return on equity & $\begin{array}{c}0.003 \\
(1.814)^{* *}\end{array}$ \\
\hline Quick ratio & $\begin{array}{c}0.003 \\
(0.932)\end{array}$ \\
\hline Dividend payout ratio & $\begin{array}{c}0.001 \\
(1.952)^{*}\end{array}$ \\
\hline Debt-to-equity ratio & $\begin{array}{c}-0.000 \\
(-1.190) \\
\end{array}$ \\
\hline Accounts receivable turnover & $\begin{array}{c}0.027 \\
(3.402)^{*}\end{array}$ \\
\hline Size & $\begin{array}{c}0.009^{* *} \\
(1.800)^{* *}\end{array}$ \\
\hline$R$-squared & 0.194 \\
\hline Adj $R$-squared & 0.193 \\
\hline SE of regression & 0.564 \\
\hline$F$-statistic & 94.768 \\
\hline Prob (F-statistic) & 0.000 \\
\hline Durbin-Watson statistic & 2.152 \\
\hline Prob ( $J$-statistic) & 0.3367 \\
\hline
\end{tabular}

positive relationship with ERP. However, economically speaking, the magnitude of the coefficient is low, which implies that the firm-level equity premium is not very dependent upon the size of the firm.

The value of the coefficient of determination $\left(R^{2}\right)$ shows that a more than $19 \%$ deviation in the model is explained by the explanatory variables. Similarly, the value of adjusted $R^{2}$ implies that the $19 \%$ variation in firm-level equity premium is explained by the model. The value of F-statistic is statistically highly significant, which implies that there is no problem in analyzing the data by way of the proposed model and technique. The DW statistic value is close to the benchmark value of 2 , which confirms that there is no problem of autocorrelation in the data. The instrument rank value used in this model is 322 . The validity of the instrument rank was checked by $J$-statistic. The statistically insignificant value of $J$-statistic indicates that the instruments are valid.

Table 7 shows the sensitivity analysis of the model. We ran the same model for different combinations of variables one by one. The results are given in columns. This shows that the signs and the significance of these variables remain the same.

For the single variable model presented in column 2, the value of the coefficient of determination $\left(R^{2}\right)$ is only $11 \%$. As the number of variables increases, the value of the $R^{2}$ also increases up to $18 \%$. Other values that show the fitness of model and data remain intact as the benchmark of these values.

\section{Conclusion and Recommendation}

This paper quantifies the impact of company fundamentals on the firm-level equity premium in an emerging market, Pakistan, using a panel data technique for 306 nonfinancial firms listed on the Pakistan Stock Exchange for the period January 2001 to December 2015. The company fundamental factors included profitability, liquidity, dividends, solvency, efficiency, and size. Based on the literature, we selected proxies for measuring company fundamentals of return on equity, quick ratio, dividend payout ratio, debt-to-equity ratio, account receivable turnover ratio, and size, as company fundamental variables as determinants of the equity premium. The company fundamentals are the controllable factors for companies and can be revisited by companies if they affect company returns.

The CAPM is not valid for the valuation of securities in the PSX. Therefore, in this study, we develop an extended version of Fama and French's [1] model, which contains seven company fundamentals, in order to test the effects on the equity premium. First, we checked the normality of the dependent variable using the Kolmogorov-Smirnov test; the results reveal that the data are normal. The results of the paired $t$-test indicate that there is no significant difference in the pre- and post-2008 global financial crisis periods. The estimated results of the equity premium and the fundamental variables show that five out of seven company fundamentals significantly affect the equity premium. These variables are the market premium, return on equity (ROE), the dividend payout ratio (DPR), the accounts turnover ratio (ATR), and the size of the firm. Of these five variables, the market premium, the dividend payout ratio, and the accounts receivable turnover have a positive, significant effect on the firm-level equity premium at a 5\% level of significance. However, ROE and size have positive and statistically significant effect on the firm-level equity premium at a $10 \%$ level of significance. This implies that an increase in the market index, high dividend payment, and good cash inflows increase the market value of individual stocks, which generates a high premium. The results also reveal that the quick ratio (QR) has a positive effect and debt-to-equity (DER) ratio has a negative, but statistically insignificant, effect on the firm-level equity premium.

The paper has some important implications for policy makers. The firm's managers can manage these company fundamentals in the best interests of the company in order to maximize shareholder wealth. But fund managers need to observe company fundamentals before making any investment decision as to an individual firm's stocks. It is also evident for policy makers that an increase in the interest rate leads to a decrease in the equity premium. Therefore, policy makers need to control interest rates in order to 
TABLE 7: Estimated results of equity premium: robustness analysis.

\begin{tabular}{|c|c|c|c|c|c|c|}
\hline Variable & $(1)$ & $(2)$ & (3) & $(4)$ & $(5)$ & $(6)$ \\
\hline Constant & -0.165 & -0.151 & -0.15 & -0.167 & -0.173 & -0.178 \\
\hline \multirow{2}{*}{ Market premium } & 0.551 & 0.352 & 0.331 & 0.401 & 0.468 & 0.501 \\
\hline & $(24.656)^{*}$ & $(7.123)^{*}$ & $(9.324)^{*}$ & $(12.198)^{*}$ & $(16.876)^{*}$ & $(20.159)^{*}$ \\
\hline \multirow{2}{*}{ Return on equity } & 0.003 & 0.002 & 0.002 & 0.002 & 0.003 & 0.003 \\
\hline & $(1.814)^{* *}$ & $(1.711)$ & $(1.804)^{* *}$ & $(1.81)^{* *}$ & $(1.811)^{* *}$ & $(1.814)^{* *}$ \\
\hline \multirow{2}{*}{ Quick ratio } & 0.003 & & 0.001 & 0.001 & 0.002 & 0.003 \\
\hline & -0.932 & & -0.811 & -0.882 & -0.901 & -0.913 \\
\hline \multirow{2}{*}{ Dividend payout ratio } & 0.001 & & & 0.001 & 0.001 & 0.001 \\
\hline & $(1.952)^{*}$ & & & $(1.943)^{*}$ & $(1.949)^{*}$ & $(1.951)^{*}$ \\
\hline \multirow{2}{*}{ Debt-to-equity ratio } & 0.00 & & & & 0.000 & 0.000 \\
\hline & $(-1.190)$ & & & & $(-1.190)$ & $(-1.284)$ \\
\hline \multirow{2}{*}{$\mathrm{A} / \mathrm{R}$ turnover (days) } & 0.027 & & & & & 0.025 \\
\hline & $(3.402)^{*}$ & & & & & $(2.398)^{*}$ \\
\hline \multirow{2}{*}{ Size } & $0.009^{* *}$ & & & & & \\
\hline & $(1.800)^{* *}$ & & & & & \\
\hline$R$-squared & 0.194 & 0.112 & 0.134 & 0.14 & 0.165 & 0.179 \\
\hline Adj $R$-squared & 0.193 & 0.123 & 0.139 & 0.148 & 0.166 & 0.181 \\
\hline SE of regression & 0.564 & 0.432 & 0.459 & 0.484 & 0.501 & 0.588 \\
\hline$F$-statistic & 94.768 & 88.132 & 88.977 & 90.373 & 92.118 & 93.631 \\
\hline Prob (F-statistic) & 0 & 0 & 0 & 0 & 0 & 0 \\
\hline Durbin-Watson statistic & 2.152 & 2.322 & 2.341 & 2.202 & 2.2 & 2.152 \\
\hline
\end{tabular}

Note. ${ }^{*},{ }^{* *}$, and ${ }^{* * *}$ indicate that variable is significant at $1 \%, 5 \%$, and $10 \%$ levels of significance.

encourage stock market investment domestically and internationally.

\section{Data Availability}

The data used to support the findings of this study are available from the corresponding author upon request.

\section{Conflicts of Interest}

The authors declare that there are no conflicts of interest regarding the publication of this paper.

\section{Acknowledgments}

The authors take this opportunity to thank the academic editor Antonio M. Lopes and annoymous reviewers for giving us valuable and insightful suggestions to improve the quality of our paper. The authors also acknowledge the financial support for this research by the National Natural Science Fund (71572071), National Social Science Foundation (19BGL127), Research and Practice Project of Teaching Reform of Graduate Education in Jiangsu Province (JGZZ1_056), and Advanced Talent Project of Jiangsu University (09JDG050 and 14JDG202).

\section{References}

[1] E. F. Fama and K. R. French, "The equity premium," The Journal of Finance, vol. 57, no. 2, pp. 637-659, 2002.

[2] R. Mehra and E. C. Prescott, "The equity premium: a puzzle," Journal of Monetary Economics, vol. 15, no. 2, pp. 145-161, 1985.
[3] A. Damodaran, "Equity risk premiums (ERP): determinants, estimation and implications-a post-crisis update," SSRN Electronic Journal, 2009.

[4] A. Damodaran, "Equity risk premiums (ERP): determinants, estimation and implications," SSRN Electronic Journal, 2016.

[5] R. A. Brealey, S. C. Myers, and F. Allen, Principles of Corporate Finance, McGraw-Hill Education, New York City, NY, USA, 8th edition, 2006.

[6] M. S. Joshi, The Concepts and Practice of Mathematical Finance, Cambridge University Press, Cambridge, UK, 2003.

[7] S. A. Ross, R. Westerfield, and J. F. Jaffe, Corporate Finance, McGraw-Hill Education, Boston, MA, USA, 7th edition, 2005.

[8] A. H. Chen and T. F. Siems, "The effects of terrorism on global capital markets," European Journal of Political Economy, vol. 20, no. 2, pp. 349-366, 2004.

[9] M. Chesney, M. Karaman, and G. Reshetar, "The impact of terrorism on financial markets: an empirical study," SSRN Electronic Journal, 2010.

[10] A. Aisen and F. J. Veiga, "How does political instability affect economic growth?" European Journal of Political Economy, vol. 29, no. 3, pp. 151-167, 2013.

[11] N. Essaddam and J. M. Karagianis, "Terrorism, country attributes, and the volatility of stock returns," Research in International Business and Finance, vol. 31, pp. 87-100, 2014.

[12] N. Essaddam and A. Mnasri, "Event-study volatility and bootstrapping: an international study," Applied Economics Letters, vol. 22, no. 3, pp. 209-213, 2014.

[13] G. Okafor, "The impact of political instability on the economic growth of ECOWAS member countries," Defence and Peace Economics, vol. 28, pp. 1-22, 2015.

[14] E. Apergis and N. Apergis, "The 11/13 Paris terrorist attacks and stock prices: the case of the international defense industry," Finance Research Letters, vol. 17, pp. 186-192, 2016.

[15] J. Hobbs, L. C. Schaupp, and J. Gingrich, "Terrorism, militarism, and stock returns," Journal of Financial Crime, vol. 23, no. 1, pp. 70-86, 2016. 
[16] A. Mnasri and S. Nechi, "Impact of terrorist attacks on stock market volatility in emerging markets," Emerging Markets Review, vol. 28, no. 3, pp. 184-202, 2016.

[17] A. Ahmad and T. Javeed, "Testing multifactor capital asset pricing model in case of Pakistani market," International Research Journal of Finance and Economics, vol. 25, pp. 114-123, 2008.

[18] M. Hanif, "Testing application of cap model on KSE-Pakistan: a case study on tobacco sector," SSRN Electronic Journal, vol. 19, no. 3, 2009.

[19] N. Shah, J. Ali Dars, and M. Haroon, "Asset pricing model conditional on up and down market for emerging market: the case of Pakistan," SSRN Electronic Journal, 2015.

[20] M. Zeeshan and M. Abdullah, "Capital asset price model empirical evidence from Karachi stock exchange," Journal of Research in Business and Management, vol. 4, no. 10, pp. 61-67, 2016.

[21] H. Markowitz, "Portfolio selection," The Journal of Finance, vol. 7, no. 1, pp. 77-91, 1952.

[22] J. Tobin, "Liquidity preference as behavior towards risk," The Review of Economic Studies, vol. 25, no. 2, pp. 65-86, 1958.

[23] W. F. Sharpe, "Capital asset prices: a theory of market equilibrium under conditions of risk," The Journal of Finance, vol. 19, no. 3, pp. 425-442, 1964.

[24] J. Lintner, "The valuation of risk assets and the selection of risky investments in stock portfolios and capital budgets," The Review of Economics and Statistics, vol. 47, no. 1, pp. 13-37, 1965.

[25] O. J. Blanchard, R. Shiller, and J. J. Siegel, "Movements in the equity premium," Brookings Papers on Economic Activity, vol. 1993, no. 2, pp. 75-138.

[26] O. A. Lamont, "Economic tracking portfolios," Journal of Econometrics, vol. 105, no. 1, pp. 161-184, 2001.

[27] M. J. Gordon and P. J. Halpern, "Bond share yield spreads under uncertain inflation," The American Economic Review, vol. 66, no. 4, pp. 559-565, 1976.

[28] A. Haque and S. Sarwar, "Effect of fundamental and stock market variables on equity return in Pakistan," Science International, vol. 25, no. 4, pp. 981-987, 2013.

[29] M. Imran, M. Wu, S. Gu, S. Saud, and M. Abbas, "Influence of economic and non-economic factors on firm level equity premium: evidence from Pakistan," Economics Bulletin, vol. 39, no. 3, pp. 1774-1785, 2019.

[30] J. Glassman and K. Hassett, "Where are stock prices headed?" The American Enterprise, vol. 10, no. 6, p. 18, 1999.

[31] P. Fernandez, "The equity premium in 150 textbooks," SSRN Electronic Journal, 2010.

[32] J. Mossin, "Equilibrium in a capital asset market," Econometrica, vol. 34, no. 4, pp. 768-783, 1966.

[33] R. Roll, "A critique of the asset pricing theory's tests part I: on past and potential testability of the theory," Journal of Financial Economics, vol. 4, no. 2, pp. 129-176, 1977.

[34] M. M. Carhart, "On persistence in mutual fund performance," The Journal of Finance, vol. 52, no. 1, pp. 57-82, 1997.

[35] E. F. Fama and K. R. French, "Size and book to market factors in earnings and returns," Journal of Finance, vol. 50, no. 1, pp. 131-155, 1995.

[36] R. Waheed, C. Wei, S. Sarwar, and Y. Lv, "Impact of oil prices on firm stock return: industry-wise analysis," Empirical Economics, vol. 55, no. 2, pp. 765-780, 2018.

[37] X. Long, Y. Chen, J. Du, K. Oh, and I. Han, "Environmental innovation and its impact on economic and environmental performance: evidence from Korean-owned firms in China," Energy Policy, vol. 107, pp. 131-137, 2017.

[38] M. Arellano, "Modelling optimal instrumental variables for dynamic panel data models," Research in Economics, vol. 70, no. 2, pp. 238-261, 2016.

[39] J. M. Wooldridge, "Instrumental variables estimation with panel data," Econometric Theory, vol. 21, no. 4, pp. 865-869, 2005.

[40] J. Durbin and A. Stuart, "An experimental comparison between coders," Journal of Marketing, vol. 19, no. 1, pp. 54-66, 1954.

[41] J. A. Hausman, "Specification tests in econometrics," Econometrica, vol. 46, no. 6, pp. 1251-1271, 1978.

[42] H. Sun, B. K. Edziah, C. Sun, and A. K. Kporsu, "Institutional quality, green innovation and energy efficiency," Energy Policy, vol. 135, Article ID 111002, 2019.

[43] R. W. Banz, "The relationship between return and market value of common stocks," Journal of Financial Economics, vol. 9, no. 1, pp. 3-18, 1981. 